\title{
QUANDO AS COMUNIDADES FAZEM SUAS BARREIRAS FRENTE À PANDEMIA: ESTRATÉGIAS DE DEFESA DA VIDA E DOS TERRITÓRIOS DAS COMUNIDADES CAIÇARAS DE TRINDADE E PRAIA DO SONO, PARATY-RJ, BRASIL ${ }^{1}$
}

\section{Cuando las comunidades hacen sus barreras frente a la pandemia: estrategias de defensa de la vida y de los territorios de las comunidades caiçaras de Trindade y Praia do Sono, Paraty-RJ, Brasil}

\author{
Amanda Regis Faro \\ Mestre em Gestão de Áreas Protegidas pelo INPA \\ amandafaro@gmail.com \\ Licio Caetano do Rego Monteiro \\ Doutor em Geografia pela UFRJ \\ liciocaetano@gmail.com \\ Jardson dos Santos \\ Líder Caiçara de Praia do Sono, Paraty-RJ \\ jadson.praiadosono@gmail.com \\ Davi Paiva \\ Jornalista e Líder Caiçara da Trindade, Paraty-RJ \\ detrinda@gmail.com \\ Ricardo Papu Martins Monge \\ papu.ecuador@gmail.com \\ Doutor em Geografia pela UFF
}

Artigo recebido em 24/02/2021 e aceito em 06/03/2021

DOI: $10.12957 /$ tamoios.2021.57985

\section{RESUMO}

Em março de 2020, a Organização Mundial da Saúde declarou a pandemia global de coronavírus. A repercussão na América Latina / Abya Yala foi imediata e diferentes medidas de confinamento e distanciamento social foram observadas. Como a pandemia pode fazer emergir, revelar e produzir barreiras e controles de populações e territórios que antes pareciam adormecidos ou latentes? Como algumas formas de barreiras são feitas não só pelo Estado, mas também por iniciativa das comunidades? A experiência social da pandemia e das formas de enfrentamento comunitário tem muito a nos ensinar sobre a dinâmica socioterritorial e política que ocorre hoje em vários cantos do continente. Este artigo apresenta as experiências de barreiras comunitárias feitas em duas comunidades tradicionais caiçaras no município de Paraty, estado do Rio de Janeiro, Brasil. São as comunidades da Praia do Sono e Trindade que promoveram bloqueios em defesa da vida e do território, em situações de conflito e negociação com os poderes do Estado. As comunidades caiçaras são grupos que se formaram a partir da mistura étnicocultural entre povos indígenas, colonos europeus e descendentes de africanos escravizados, assentados em áreas litorâneas entre os estados do Paraná e Rio de Janeiro. Essas comunidades são historicamente marcadas por conflitos e lutas territoriais. As barreiras foram estabelecidas através de arranjos comunitários, dada a impossibilidade de 
o poder público garantir o isolamento e a segurança física destas populações tradicionais, constantemente assediadas pelo turismo. Fazer a barreira não tem apenas como significado o fechamento de territórios, mas também a construção de formas mais autônomas de gestão da vida.

Palavras-chave: barreiras comunitárias; comunidades caiçaras; território; Paraty.

\section{RESUMEN}

En marzo de 2020 la Organización Mundial de la Salud declaró la pandemia global del coronavirus. La repercusión en América Latina/Abya Yala fue inmediata y fueron vistos diferentes medidas de confinamiento y distanciamiento social. ¿Cómo la pandemia puede hacer emerger, evidenciar y producir barreras y controles de poblaciones y territorios que antes parecían adormecidos o latentes? ¿Cómo algunas formas de barreras son hechas no solamente por el Estado, pero también por la iniciativa de las comunidades? La experiencia social de la pandemia y del enfrentamiento comunitario tiene mucho a enseñarnos sobre las dinámicas socio-territoriales y políticas que ocurren hoy en día en diversos rincones del continente. El presente artículo expone las experiencias de barreras comunitarias hechas en dos comunidades tradicionales caiçaras del municipio de Paraty, estado de Río de Janeiro, Brasil. Son las comunidades de Praia do Sono y Trindade que promovieron cierres en defensa de la vida y del territorio, en situaciones de conflicto y de negociación con los poderes del Estado. Las comunidades caiçaras son grupos que se formaron por la mezcla étnico-cultural entre pueblos indígenas, colonos europeos y descendientes de africanos esclavizados, asentados en zonas costeras entre los estados de Paraná y Río de Janeiro. Estas comunidades han estado históricamente marcadas por conflictos y luchas territoriales. Los cierres fueron establecidos a través de arreglos comunitarios, ante la incapacidad del poder público para garantizar el aislamiento y la seguridad física de estas poblaciones tradicionales, que son constantemente acosadas por el turismo. Hacer la barrera no tiene solamente el sentido de cierre de territorios, pero también el de producir maneras más autónomas de gestión de la vida.

Palabras-clave: barreras comunitarias; comunidades caiçaras; territorio; Paraty. 
Na história de nosso povo, de tempos em tempos somos colocados diante de situações que nos convocam para a luta. Nossos pais e avós lutaram para que tivéssemos o direito de permanecer em nosso território. Agora lutamos para que eles tenham o direito de permanecer conosco.

Mensagem em vídeo publicado em defesa da barreira comunitária da Praia do Sono

\section{PANDEMIA, FECHAMENTO DE FRONTEIRAS E COMUNIDADES EM DIFERENTES ESCALAS}

Em toda a América Latina / Abya Yala, vimos diferentes medidas de confinamento e distanciamento social. Os países fecharam suas fronteiras e aeroportos. Os estados limitaram a circulação interna, as cidades bloquearam suas entradas. A epidemia da Covid-19 impôs a ativação de diferentes fronteiras e barreiras. A mais óbvia foi a fronteira nacional, os fechamentos que ocorreram em todo o mundo e em nosso continente. Também tivemos a notícia do surgimento de barreiras e controles em níveis subnacionais, nas divisas entre estados e municípios. Mas também os povos fizeram suas barreiras de auto-isolamento, para fechar e proteger suas comunidades, afirmando sua autonomia e seus territórios.

Como a pandemia pôde fazer emergir, revelar e produzir barreiras e controles de populações e territórios que antes pareciam adormecidos ou latentes? E como algumas formas de barreiras são feitas não só pelo Estado, mas também por iniciativa das comunidades? Este artigo discute as experiências de barreiras comunitárias feitas em duas comunidades tradicionais caiçaras de Paraty, no estado do Rio de Janeiro: as comunidades da Praia do Sono e Trindade.

Em 11 de março de 2020, a Organização Mundial da Saúde declara a pandemia global de coronavírus. A repercussão na América Latina / Abya Yala foi imediata. No dia 16 de março, representantes oficiais dos países da América do Sul, sem a participação do Brasil, apontaram a necessidade de medidas restritivas, como o fechamento de fronteiras, que evoluiu muito rapidamente em todo o continente, afetando o fechamento de voos internacionais. As medidas foram tomadas a partir de lógicas nacionais ou mesmo subnacionais, com baixa coordenação regional (REGO MONTEIRO et al., 2020; REGO MONTEIRO, 2020).

O tema do nosso artigo é outro tipo de fechamento frente à pandemia, trata-se dos fechamentos feitos por comunidades tradicionais em defesa da vida e do território, dada a ineficácia do Estado em garantir as condições de seu isolamento e segurança sanitária. Utilizamos o conceito de território como categoria prática dos movimentos sociais e das 
relações de poder, tanto na dimensão do poder político com seus múltiplos sujeitos de poder, quanto no sentido simbólico-cultural, do vivido e das identidades (HAESBAERT, 2014). Tomamos como exemplo de luta duas comunidades tradicionais caiçaras do município de Paraty (RJ). A experiência social da pandemia e do enfrentamento comunitário tem muito a nos ensinar sobre a dinâmica socioterritorial e política que ocorre hoje em vários cantos do continente.

Segundo Raquel Gutiérrez, "para estudar as lutas e aprender com elas é necessário um caminho para torná-las compreensíveis, compreender suas possibilidades transformadoras e torná-las comparáveis entre si, mesmo em sua singularidade" $(2016, p$. 32). Partimos da análise do "artefato" proposto por Gutiérrez: "contraste sistemático do horizonte interior manifestado nas ações para desafiar a ordem estabelecida com o alcance prático - material e simbólico - de tais ações e lutas" (2016, p.32) O escopo prático consiste em

\begin{abstract}
el conjunto de rasgos y significados plenamente registrables a partir del seguimiento de la propia acción de lucha: su carácter local, regional, nacional o internacional; su capacidad para trastocar y suspender la normalidad capitalista de la vida cotidiana; la manera en la que rompe los tiempos dados y preestablecidos de la acumulación de capital y del mando político estatal, etc. El registro minucioso del despliegue de las luchas en sus alcances prácticos ilumina y permite percibir, también, el horizonte interior que se abre paso a través de ellas o las dificultades para que ciertos rasgos broten o se expresen (GUTIÉRREZ, 2016, p. 32).
\end{abstract}

O alcance prático das experiências locais de Trindade e Praia do Sono apresentase através da suspensão da normalidade dos fluxos da vida cotidiana e da economia do turismo, afetando até mesmo a renda local de forma contraditória. Surge assim a dimensão comunitária da vida social em superposição aos interesses econômicos locais e, principalmente, à demanda municipal de abertura para a circulação de turistas. Nesse sentido, o que é, antes de mais nada, uma atitude defensiva e pragmática acaba se tornando conflituosa e desafiadora da ordem estabelecida, uma vez que evidencia os interesses diferenciados do Estado, dos empresários e das comunidades no contexto da região.

Assim, para conhecer as lutas a partir das próprias lutas, como sugere Gutiérrez, este trabalho foi construído por meio de um diálogo entre pesquisadores e duas lideranças caiçaras da Praia do Sono e de Trindade, profundamente envolvidas com a construção e manutenção de barreiras sanitárias nessas comunidades. Esse diálogo se deu tanto por meio da participação em grupos de articulação política da comunidade, na perspectiva da 
pesquisa militante (BONILLA et al., 1972), quanto pelo acompanhamento das lutas por meio de veículos de informação pública e entrevistas semiestruturadas realizadas com essas lideranças. Ressaltamos a importância de inovações metodológicas para realizar pesquisas desse tipo em um contexto pandêmico, com restrições para atuação no campo, por isso as relações de confiança construídas durante anos de pesquisa e ação política nos territórios foram muito importantes.

\section{FRENTE À PANDEMIA: AS RESPOSTAS DOS POVOS E COMUNIDADES}

As lógicas e as relações de opressão e dominação originadas na conquista ibérica do que veio a ser chamado de continente americano consolidaram-se como padrão mundial de poder hegemônico até hoje, conforme aponta Cruz (2017). A recente pandemia de Covid-19 evidenciou a colonialidade como uma relação social, cultural e intelectual que não terminou com o fim do colonialismo. É o que se ouve na canção de Kaê Guajajara (2020): "Há 500 anos a epidemia mata o maior grupo de risco". Uma declaração conjunta de organizações indígenas mexicanas explicou:

\footnotetext{
Aun con todo esto seguiremos resistiendo como siempre nos lo han hecho nuestros ancestros frente a la muerte que hoy representa esta pandemia como lo fue hace 528 años cuando cayó la ciudad Tenochtitlán y la enfermedad que trajeron los españoles a nuestros pueblos mesoamericanos, y por otra parte el genocidio invasión a nuestro territorio en la época colonial (CIPOG-EZ et al., 2020).
}

A guerra contra os povos já dura bastante tempo e as memórias coletivas mostram a continuidade da linha colonial que se manifesta nestas situações. A canção de Kaê Guajajara (2020) começa afirmando que "não foi só bala que matou" os indígenas, mas também as epidemias, revertendo a relativização da violência da colonização que enfatiza a doença como principal causa do genocídio dos povos do continente. É fato que houve doenças e epidemias, mas as epidemias ocorreram em contextos de impossibilidade de proteção e defesa.

Hoje, a pandemia de coronavírus revela como seus efeitos atingem diferentes segmentos da população em um sistema altamente desigual. Talvez só hoje, perante uma nova catástrofe humanitária, possamos compreender o real significado de uma pandemia na organização do território e na gestão das populações. Isso também está muito claro no manifesto: 
Como pueblos originarios, hemos entendido, que la enfermedad del coronavirus es un motivo para ejercer control hacia nuestros pueblos y nuestro territorio. Al parecer, el coronavirus no va únicamente por la salud/vida humana, sino por las riquezas y por los pueblos en resistencias que aún subsisten en los territorios indígenas y del mundo (CIPOG-EZ et al., 2020).

Para as pessoas de hoje em dia, o fato de a maior parte da população originária de nosso continente ter morrido pelos efeitos de epidemias trazidas do exterior ganha um novo significado. A memória colonial se soma à memória das colonizações internas dos territórios, quando, em diferentes momentos, a expansão das fronteiras econômicas resultou na imposição violenta de deslocamentos populacionais, alteração de ecossistemas e exposição de populações nativas a doenças contagiosas que ganharam rápida disseminação com a abertura de estradas e atividades extrativistas.

No Brasil, uma das principais revelações da Comissão Nacional da Verdade (CNV, 2014) foi a de que milhares de indígenas foram aniquilados durante a ditadura militar, em um contexto de acúmulo de terras e expansão das fronteiras econômicas. Naquela época, o dilema entre preservar vidas ou beneficiar empresários surgira para o governo militar, e os índios não foram poupados. Mas, como diz Kaê Guajajara, "não foi só bala”. Houve envenenamento e guerra biológica. Estima-se que 3.500 indígenas da etnia Cinta-Larga em Rondônia foram exterminados e uma das armas utilizadas foi a "doação" de brinquedos e roupas contaminadas para propagar intencionalmente a gripe nas aldeias. Entre os Yanomani, a comissão da FUNAI resultou na rápida disseminação do sarampo, gripe, malária, caxumba e tuberculose. Houve 354 mortes e mais de 700 indígenas afetados em várias aldeias, representando altas porcentagens da população total de Yanomani.

A Comissão Nacional da Verdade chegou a um número de 8.350 casos de indígenas mortos por conta da ditadura militar. Histórias que passaram a ser relatadas apenas décadas após o evento, com base em entrevistas de sobreviventes e poucos registros documentais. Mesmo o pequeno esforço de memória, justiça e reparação já foi interrompido e com o passar do tempo fica mais difícil recuperar a história das violências ocorridas. Recontá-lo não é apenas uma questão importante para os que se foram, mas sobretudo para que possamos enxergar a violência que não foi interrompida com o fim da ditadura militar e persistiu em inúmeros massacres, exposições a doenças, assassinatos de indígenas, violações do território e dos meios de subsistência dos povos nativos.

A Comissão Nacional da Verdade também buscou recuperar os autos de conflitos no campo no estado do Rio de Janeiro. O relatório indica que a região da Baía da Ilha 
Grande, da qual fazem parte o município de Angra dos Reis e Paraty, foi a região com maior número de conflitos de terra no estado do Rio de Janeiro. As comunidades da Praia do Sono e Trindade estiveram entre as envolvidas nos conflitos de terra, devido à ação de grileiros e empresas estrangeiras favorecidas pelo governo militar. Nas décadas de 1970 e 1980, Praia do Sono e Trindade sofreram pressões para a criação de condomínios e grandes hotéis no litoral de Paraty, devido ao turismo de luxo e de massas que se instalou na região como uma nova frente de expansão de capital (SIQUEIRA, 1984; FEITOSA; SILVA, 2015).

Os relatórios da Comissão Missionária Indígena (CIMI) e da Comissão Pastoral da Terra (CPT) atualizam ano após ano o quadro de violência que não cessa no período pós-ditadura, apesar dos pequenos avanços na demarcação territorial e no reconhecimento de direitos no nos últimos 30 anos. Dados da CPT (2020) mostram um panorama dos conflitos rurais no Brasil, indicando que entre 2010 e 2019 ocorreram 368 homicídios por conflitos de terra. Essa realidade infelizmente não está longe de Paraty, onde em 2016 a comunidade da Trindade viveu o trágico assassinato do jovem Jaison Caique Sampaio, conhecido por todos como "Dão", pelos seguranças de uma imobiliária que pretendia expandir seu terreno (LEPERCQ / Rio On Watch, 2016).

Esse quadro da situação brasileira pode ser comparado com outros países da América Latina / Abya Yala. Além da colonização que marcou a expropriação territorial no passado remoto, temos em períodos mais recentes diferentes combinações entre regimes autoritários, violência ilegal e frentes econômicas extrativas que marcam a degradação das condições de sobrevivência dos povos e comunidades indígenas e tradicionais em todo o continente. As condições de insegurança jurídica dos territórios comunitários, o descaso das autoridades públicas em matéria de saúde e proteção de vidas e a vulnerabilidade ao extrativismo de toda espécie geram pressões que dificultam muito o combate à atual pandemia no contexto desses lugares.

\section{DAS FRONTEIRAS ESTATAIS ÀS BARREIRAS COMUNITÁRIAS}

Para pensar o território e as estratégias de fechamento e controle, contamos com vários níveis de análise: fronteiras nacionais, divisas estaduais, departamentais e intermunicipais, espaços privados e públicos, barreiras comunitárias, espaços domésticos e os próprios corpos. Em divisas e fronteiras subnacionais, como as existentes entre unidades federativas, municípios e regiões, as regras e bloqueios impostos pelos governos 
subnacionais resultaram na desconexão de espaços que não tinham memória anterior de bloqueios, tornando visíveis as fronteiras que estiveram adormecidas por muitas décadas. A desconexão também é apresentada pela interrupção do fluxo de ônibus e controles de tráfego localizados nas entradas das cidades e comunidades. Houve conflitos federativos, por exemplo, com o fechamento de rodovias ou aeroportos federais ou estaduais, e na manipulação de regras que afetam de forma diferente regiões ou cidades. Alguns tipos de controle se manifestaram no espaço urbano, como a regulamentação do comércio, dos serviços e do trânsito de pessoas nos espaços públicos e privados.

Numa escala micropolítica, podemos falar sobre os espaços e territorialidades da casa e do corpo. Na casa, os limites do espaço doméstico e a organização dos espaços interiores / exteriores. Mas também a questão do lar como espaço de intimidade e trabalho, as divisões sexuais do trabalho no lar, as relações intergeracionais, a polêmica sobre o isolamento vertical ou horizontal e mesmo o lar como espaço de risco em caso de violência contra a mulher e filhos. No que diz respeito ao corpo, os controles biométricos, sua soberania em relação ao confinamento ou à vacinação obrigatória, mas também suas extensões tecnológicas, como o telefone celular. Da mesma forma, é preciso olhar os diferentes segmentos da população, os mais vulneráveis, aqueles com menos acesso aos hospitais, os idosos, os indígenas, quem são os mais expostos.

Diferentes dispositivos de controle territorial estão sendo experimentados hoje, orientados para diversos propósitos. Há uma troca de tecnologias e regulamentações além das fronteiras nacionais e contextos internos. Barreiras e postos de controle / checkpoints, vigilância remota por monitoramento de vídeo e drones, rastreamento de celular, dados geoespaciais e controles biométricos são exemplos que passam entre fronteiras internacionais e espaços subnacionais, entre controles públicos e privados, com efeitos em corpos em movimento e os diferentes espaços. Algumas tecnologias espaciais são de uso exclusivo do Estado e das empresas, mas algumas também são apropriadas e ressignificadas por outros sujeitos. É o caso das barreiras e postos de controle / fiscalização, onde são apresentados os documentos e as licenças dos carros, um tipo de tecnologia que é mais simples e que permite o bloqueio de estradas e entradas de cidades ou comunidades.

Mas um nível territorial de grande relevância que investigamos neste artigo é a dinâmica de controle e gestão nas comunidades, onde o território emerge em seu poder, “instituído por sujeitos e grupos sociais que por meio dele se afirmam" (PORTOGONÇALVES, 2006). São os casos de contextos comunitários com decisões de 
autogestão perante o poder público, comunidades que criaram suas barreiras, seja porque já possuíam formas anteriores de separação e autogestão do território, seja porque as criaram ou evidenciaram em um contexto de emergência.

As experiências de fechamentos e barreiras comunitárias são visíveis em várias partes da América Latina / Abya Yala, mesmo antes da pandemia. Um exemplo são as comunidades zapatistas em momentos específicos de sua história de resistência ao estado mexicano. Comunidades tradicionais e indígenas reagiram com seus próprios fechamentos e regras para enfrentar a pandemia. Diante da impossibilidade de confiar no Estado e sabendo que só terão a si mesmos como último recurso diante da doença, tomaram suas decisões pensando em sua legítima defesa. Este momento pode ter consequências para além da pandemia, reforçando a autonomia política das comunidades nos seus territórios, a capacidade de autossuficiência e a sua defesa contra a deterioração das condições de subsistência em todo o continente.

No México, o Exército Zapatista fechou os "caracóis" ao contato externo ainda no dia 16 de março (EZLN, 2020), muito antes das medidas tardiamente adotadas pelo presidente López Obrador. A tendência de encerramento também foi observada em vários municípios onde as leis de usos e costumes tradicionais se sobrepõem às leis do Estado. O sucesso dos povos indígenas em conter a propagação em seus ambientes se deve menos aos esforços do governo do que à capacidade de fazer cumprir as barreiras erguidas em seus territórios e compartilhar informações e práticas de higiene. No Equador aconteceu algo semelhante. As barreiras foram erguidas com o apoio da CONAIE em comunas, vilas e comunidades de todo o território e não se desmontaram quando o governo central agendou a reabertura para 4 de maio (CONAIE, 2020).

Esperava-se que as comunidades mais isoladas estivessem menos expostas à disseminação do coronavírus. Mas, tanto no Equador quanto no Chile e no Brasil, as comunidades indígenas questionam a continuidade das atividades extrativas legais e ilegais durante a pandemia que estão colocando suas populações em risco. Tendo em vista que o capitalismo precisa se apropriar do trabalho e da natureza para garantir sua reprodução, mesmo em tempos de pandemia, a expropriação de recursos naturais na América Latina / Abya Yala é considerada uma atividade essencial pelos governos. As atividades extrativistas e o turismo são apontados como ameaças aos povos que optam por se isolar, mas que continuam a ser perseguidos pelo assédio incessante do capital (OCMAL, 16 de abril de 2020). 
De forma mais ampla, podemos dizer que as barreiras se constituíram como um contra-espaço, "o modo espacial pelo qual os excluídos e dominados questionam a ordem espacial instituída como forma de organização da sociedade” (MOREIRA, 2006), colocando em verificação da autoridade territorial exclusiva e centralizada no Estado (AGNEW e OSLENDER, 2010).

\section{BARREIRAS COMUNITÁRIAS E TERRITÓRIO EM PARATY: OS CASOS DE TRINDADE E PRAIA DO SONO}

Tomamos aqui como exemplo para nossa análise os casos de duas comunidades tradicionais caiçaras, Trindade e Praia do Sono, localizadas no município de Paraty, litoral sul do estado do Rio de Janeiro. As comunidades caiçaras são grupos que, no passado, foram formados pela mistura étnico-cultural entre povos indígenas, colonos europeus e descendentes de africanos escravizados, assentados em áreas litorâneas entre os estados do Paraná e Rio de Janeiro (DIEGUES, 2002). Essas comunidades têm sido historicamente marcadas por conflitos e lutas territoriais (SIQUEIRA, 1984; MONGE, 2019; FARO, 2019; LOPES, 2020), que se organizaram em diferentes momentos diante de um conjunto de forças e tensões econômicas, políticas e culturais, que desde a década de 1950 tiveram o turismo como eixo.

O turismo foi o principal projeto econômico promovido pelo Estado para o município de Paraty nas últimas décadas e mobilizou diversos agentes de transformação territorial: a especulação imobiliária (instalação de grandes condomínios de luxo e privatização de praias por veranistas das grandes capitais do país), gestão ambiental pública (diversas áreas naturais protegidas presentes na região) e massiva visitação turística. A cidade de Paraty, que possui uma população de 43.680 habitantes (IBGE, 2020), está situada equidistante entre as principais capitais econômicas do país, Rio de Janeiro e São Paulo (Figura $N^{\circ}$ 1), com ligações rodoviárias (viagens de 4 a 5 horas de carro ou ônibus) e infraestrutura de marinas, heliportos e um pequeno aeroporto. 


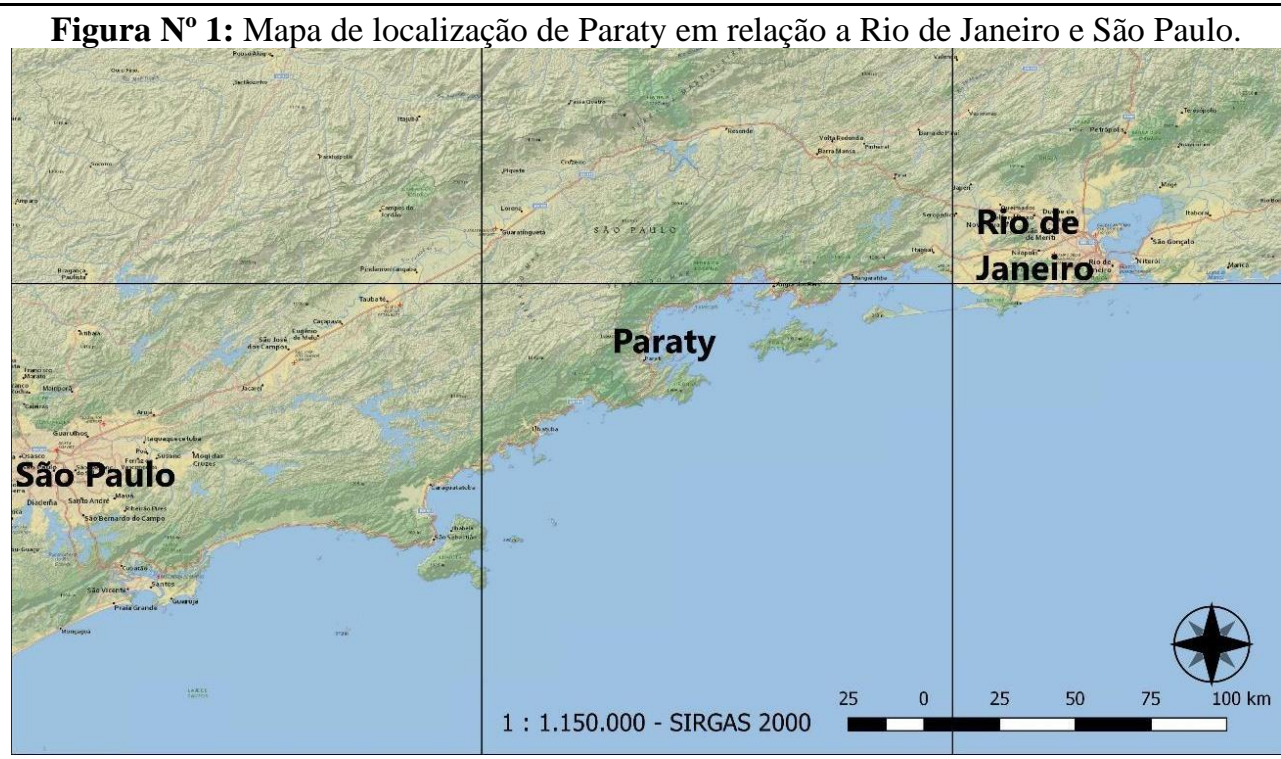

Fonte: Qgis / Bing Map - elaboração: Ricardo Monge

A cidade é internacionalmente conhecida por suas belezas naturais e rica paisagem histórica, tem o turismo como a principal fonte de renda de sua população, seja através do setor de serviços, comércio ou até mesmo da construção civil. Recentemente a cidade (juntamente com a parte insular da vizinha Angra dos Reis) foi declarada Patrimônio Cultural e Natural da Humanidade pela UNESCO, título que estabelece a área como um sítio misto, por entender que a excepcionalidade está justamente na interação entre o ambiente natural preservado e os povos tradicionais indígenas, caiçaras e quilombolas que habitam a região há séculos. Essas comunidades, cuja principal característica é a dependência do território para sua reprodução física e simbólica, conciliam com o turismo suas atividades tradicionais, como a agricultura, a pesca e o extrativismo. A preservação cultural e natural, por sua vez, está ameaçada por empreendimentos turísticos e imobiliários de negócios na região, que inclui Angra dos Reis, como é o caso da proposta de tornar a região uma "Cancún brasileira" (REGO MONTEIRO, 2020; CARVALHO, 2020)

A comunidade da Trindade, situada a 25 quilómetros do centro urbano através da rede rodoviária, é um dos principais destinos turísticos da cidade e possui um pequeno núcleo urbanizado, com pequenos mercados, farmácia, comércio, restaurantes, hospedagens que "convivem" entre canoas, redes e fazendas de pesca. Possui também algumas organizações comunitárias, como a Associação de Moradores de Trindade (AMOT) e a Associação de Barqueiros e Pescadores Artesanais de Trindade (ABAT). Nessa comunidade, muitos moradores não são nativos, ou seja, não são caiçaras. A 
comunidade da Praia do Sono, que também é um importante destino turístico, é um povoado pequeno e mais isolado, onde, junto com as casas de nativos e os equipamentos de pesca, também existem pousadas e restaurantes. Esta comunidade localiza-se a cerca de 29 quilômetros do centro urbano, acessível apenas via trilha ou marítima e também é organizada através da Associação de Moradores Originários da Praia do Sono AMOSONO. Marcadas por uma história de conflito, luta e marginalização por parte do Estado, em face da disseminação da Covid-19, essas comunidades continuaram buscando seus próprios caminhos para garantir sua existência.

O governo brasileiro decretou estado de calamidade pública no Brasil em 20 de março de 2020, enquanto em 16 de março já havia sido decretada situação de emergência no estado do Rio de Janeiro. O governo municipal de Paraty respondeu inicialmente à situação da pandemia com a suspensão de aulas em 16 de março, convocando representantes do setor turístico para definir algumas restrições, como a redução dos serviços de assistência turística e a suspensão do transporte turístico no município. No dia 18 de março, é declarada a situação de emergência em Paraty e, então, por decreto, é estabelecido o fechamento de todas as lojas, a suspensão dos serviços considerados não essenciais e a proibição de circulação e permanência em todas as praias, trilhas e cachoeiras. O fechamento dos limites municipais, por sua vez, só entrou em vigor no dia 22 de março, mas o controle concentrou-se apenas no centro urbano, deixando várias comunidades indefesas, que se encontravam fora desse raio de fiscalização. Diante da pressão dos setores econômicos municipais, a cidade tentou a abertura do comércio e a permissão para a realização de serviços religiosos, mas teve que retornar após denúncias de cidadãos ao Ministério Público, órgão de controle do Estado brasileiro. Porém, em 2 de junho, por meio de decreto municipal, foi estabelecido um sistema de bandeiras (identificadas por cores) com o objetivo de instituir um plano de transição gradual para o chamado "novo normal”. Este sistema leva em consideração 11 indicadores projetados para medir a taxa de disseminação de Covid-19 e a capacidade de serviço no sistema de saúde. Na mesma data, de acordo com o cenário do município em relação à pandemia que até então havia totalizado 108 casos confirmados de contaminação pela Covid-19, 239 casos suspeitos, 5 óbitos e 9\% de leitos hospitalares ocupados - a situação foi enquadrada no Bandeira vermelha, permitindo a abertura de lojas e serviços não essenciais. Porém, em 31 de julho, quando o município atingiu 627 casos confirmados de contaminação por Covid-19, 956 casos suspeitos, 24 óbitos e 44\% dos leitos hospitalares em uso, contraditoriamente a prefeitura tornou a regulamentação mais permissiva, 
alterando o marcado pelo a bandeira azul, que, além de manter todos os comércios e serviços abertos, também promove a abertura da cidade ao turismo.

Neste contexto de extrema vulnerabilidade social, surgiram algumas iniciativas autônomas de barreiras sanitárias comunitárias (Figura $\mathrm{N}^{\circ} 2$ ), que serão aqui descritas com base nas informações dos líderes caiçaras de Trindade e Praia do Sono, Davi Paiva e Jardson dos Santos, respectivamente.

\section{COMUNIDADE CAIÇARA DE TRINDADE}

Diante de um cenário que exige urgência na tomada de decisões, os moradores de Trindade, por meio de petição feita virtualmente, com a coleta de 1.223 assinaturas, decidiram criar uma barreira sanitária na comunidade, solicitando o apoio das autoridades municipais para tal. Segundo o depoimento de uma liderança caiçara de Trindade que acompanhou todo o processo, a principal preocupação dos moradores era o grande potencial de disseminação do vírus na comunidade, já que além de ser um local muito visitado, abriga uma comunidade tradicional que possui dinâmicas sociais que incluem costumes culturais coletivos, de convivência próxima no seio da família extensa, que geralmente possui muitos idosos. Percebendo que a cidade não conseguia responder rapidamente à necessidade de isolamento social, alguns jovens de Trindade, apoiados pela Associação de Moradores de Trindade, tomaram a iniciativa de bloquear a via de acesso da comunidade a partir de 20 de março (Figura $n^{\circ} 3$ ). A estrutura física da barreira e a alimentação dos voluntários foi obtida com o apoio da AMOT e da Associação de Surf de Trindade, que disponibilizaram tendas, mesas e cadeiras. A prefeitura de Paraty auxiliou na instalação de banheiros químicos e ocasionalmente com alguns materiais de higiene. 
Figura $\mathbf{N}^{\mathbf{0}}$ 2: Mapa da cidade de Paraty. Seção espacial do trajeto entre o centro urbano municipal e as comunidades de Praia do Sono e Trindade. Destaque para a localização da barreira da Praia do Sono (B-PS) y la barrera de Trindade (B-T).

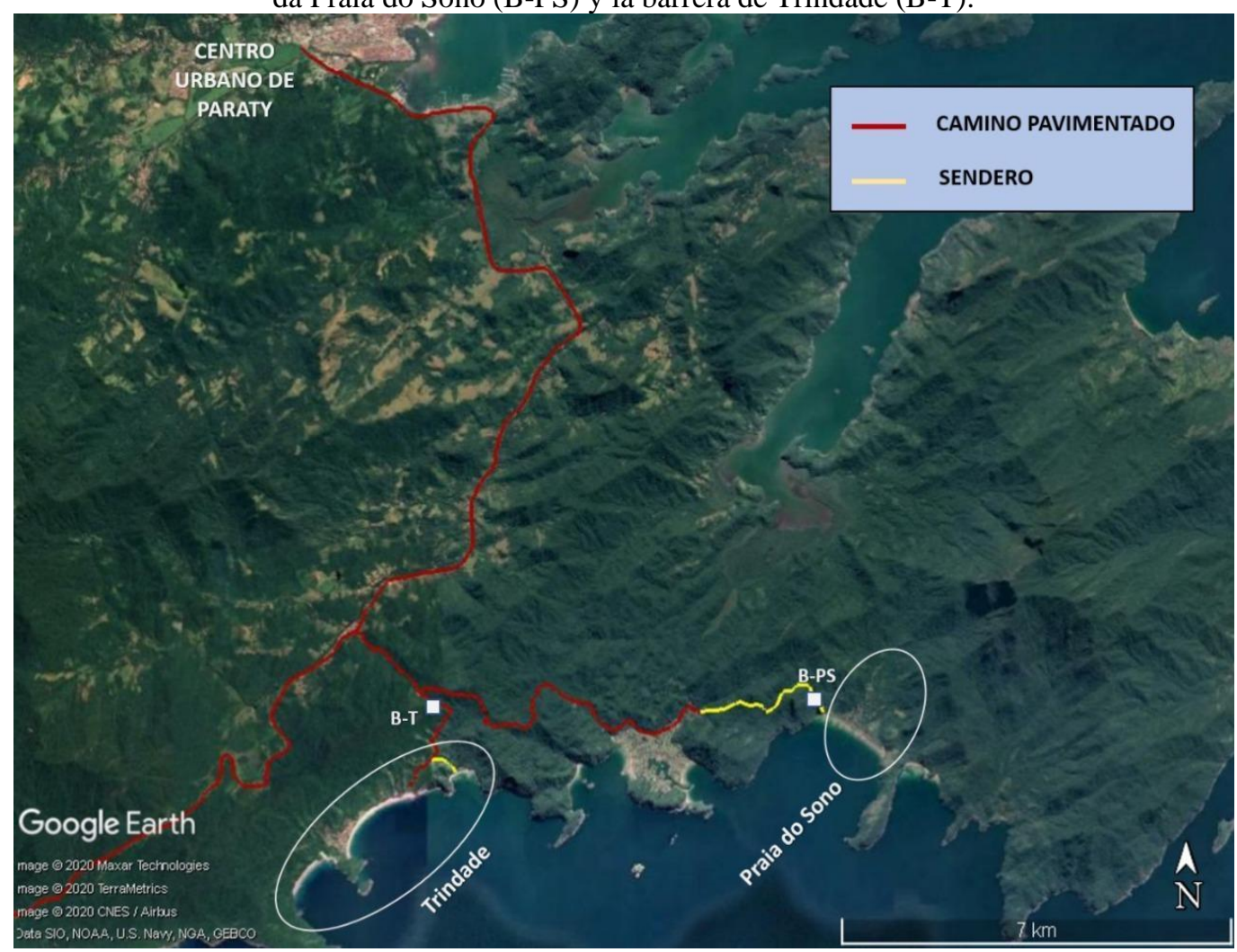

Fonte: Google Earth - elaboração: Amanda Faro

A barreira, formada por voluntários residentes, durou 147 dias. Passaram pela barreira 161 pessoas da comunidade dispostas a ajudar, em 588 plantões, já que a barreira funcionava 24 horas por dia. Ficou estabelecido que só podiam entrar e sair moradores de Trindade. Turistas, veranistas (pessoas que possuem algum imóvel no bairro, mas não moram nele) e até mesmo parentes dos moradores, que não moravam no bairro, foram bloqueados. Dentre as dificuldades relacionadas à organização da barreira, a comunidade relata que a divisão dos plantões foi uma tarefa bastante complexa, pois envolveu a disponibilidade de muitas pessoas. A divisão diária era realizada em 4 turnos, com média de 4 pessoas por turno. Algumas pessoas ficaram encarregadas de organizar as escalas, que eram lançadas semanalmente. Para isso, foi formado um grupo virtual com todos os que se ofereceram para permanecer na barreira, no qual foram indicados os períodos da semana (dias e horários) em que cada um estaria disponível. Alguns grupos acabaram sendo fixados em determinados horários. Porém, houve muita rotatividade de pessoas na barreira: nem todas as pessoas que iniciaram o movimento ficaram até o final e outras, por sua vez, se voluntariaram no meio do processo. Na barreira, foram coletados dados 
de todas as pessoas que passaram e, quando possível, de pessoas proibidas, incluindo informações sobre os motivos da visita.

Figura $\mathbf{N}^{\circ}$ 3: Barrera de la comunidad de Trindade en el turno de la noche.

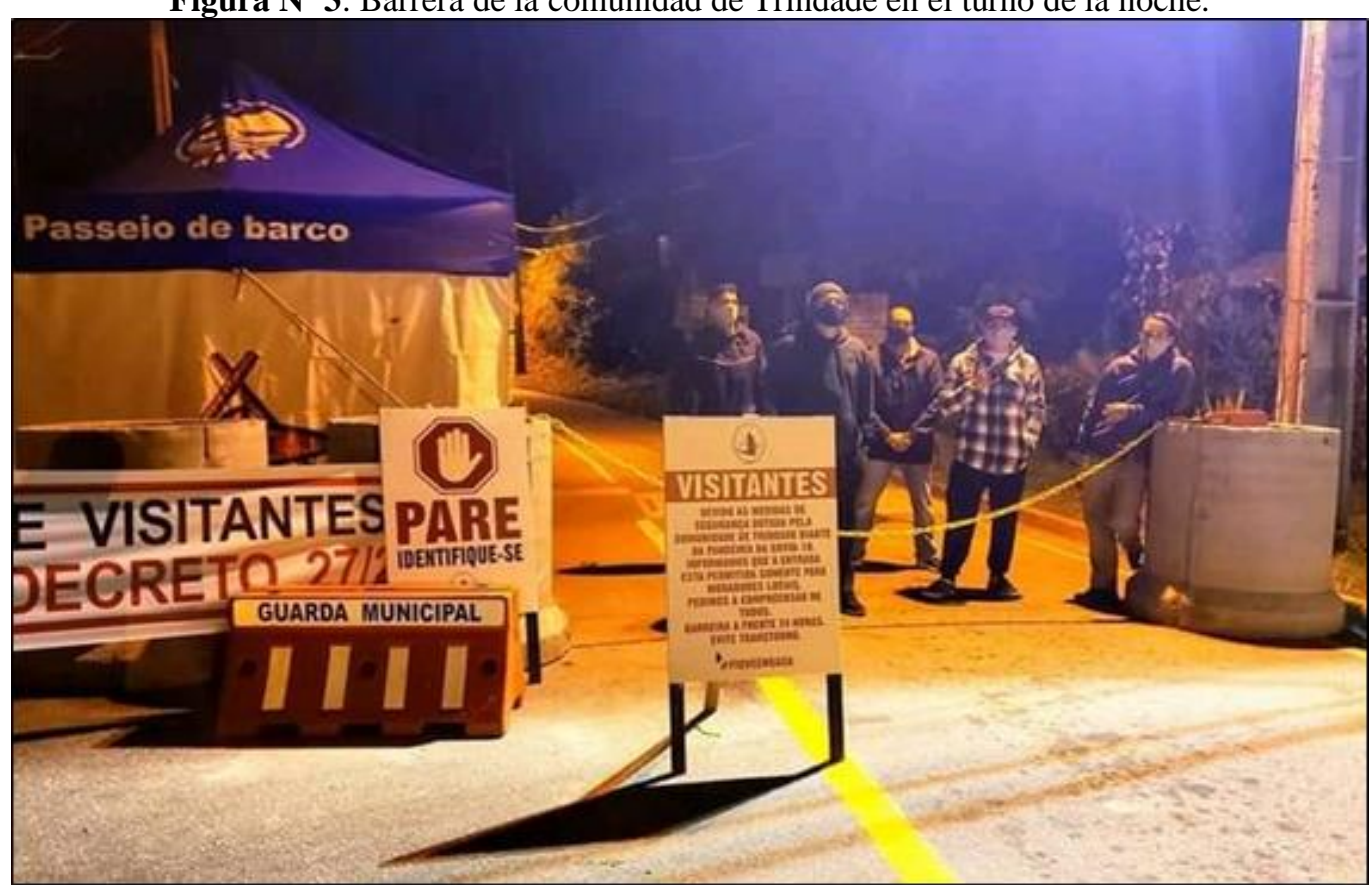

Fonte: Davi Paiva

Durante a existência da barreira, ocorreram conflitos de várias naturezas, daqueles envolvendo pessoas que, de alguma forma, não compreendiam a importância da comunidade, restringindo a passagem apenas aos habitantes de Trindade, como os de natureza econômica. Muitas pessoas se opuseram à barreira: alguns moradores de outros bairros de Paraty, que queriam curtir as praias; surfistas, que até tentaram assinar uma petição para reverter o bloqueio; parentes de vizinhos, que até se esconderam em carros para entrar na comunidade, entre outros. Um dos principais conflitos era a proibição de passagem de funcionários de pousadas e lojas que não residiam na comunidade. Esse conflito gerou tanta pressão que acabou sendo um dos primeiros setores a se flexibilizar, o que aconteceu aos poucos. Os funcionários começaram a entrar na comunidade após o registro de cada um deles. Moradores também relatam que algumas pessoas tentaram tirar proveito de seus cargos, como vereadores e advogados, para romper a barreira.

Uma contradição que se tornou evidente durante o processo de mobilização da comunidade para a barreira foi a relação que algumas pessoas / grupos têm com o território da Trindade, demonstrada a partir de duas lógicas: aquela que vê o território apenas como local a ser explorado para o turismo, para obter lucro e que, portanto, coloca os interesses individuais antes dos coletivos; e um que reconhece a necessidade de 
proteger as pessoas como uma prioridade, e cujos interesses estão na comunidade. Segundo um dos líderes, Davi Paiva, as pessoas que colocam o lucro em primeiro lugar, de alguma forma, não se identificam, não conhecem ou não reconhecem as particularidades da comunidade tradicional caiçara. Segundo essa liderança, a maioria dos comunitários, que historicamente lutaram contra a especulação imobiliária, era favorável à barreira, ou mesmo se voluntariava para ajudar nos plantões. Por outro lado, pessoas cujo único objetivo era gerar renda - geralmente pessoas que não têm família ou vínculo com o local - manifestaram-se contra a barreira. No entanto, ele acrescenta que não se trata de uma simples oposição entre os nativos ou não, e que a complexidade está na cosmovisão. Com o que podemos inferir que os laços de práticas de solidariedade e cooperação não podem ser vistos como essência ou instinto, mas são produzidos ativamente (GUTIERREZ, TRUJILLO e LINSALATA, 2016), principalmente quando o território é visto de uma perspectiva integradora, segundo Haesbaert (2013), entre a sua funcionalidade e a imaterialidade.

A prefeitura de Paraty, por meio de decreto de 2 de junho, que instituiu um sistema de bandeiras para determinar a flexibilização das restrições diante da pandemia, determinou a bandeira vermelha, que estabelece a reabertura de lojas e serviços não essenciais, mas mantém a proibição de atividades turísticas. Diante dessa flexibilidade do poder público, os moradores de Trindade solicitaram oficialmente à prefeitura que mantivesse o isolamento social e restringisse o acesso à comunidade tradicional caiçara. A decisão da comunidade baseou-se numa investigação presencial, realizada casa a casa, realizada entre os dias 16 e 24 de junho, através da qual foram consultados 376 residentes, dos quais $93 \%$ votaram a favor da continuidade da barreira.

A partir desse momento, uma série de encontros comunitários começaram a acontecer como forma de organizar a barreira contra as pressões e tensões que lhe eram impostas. No dia 25 de junho, foi realizada a primeira reunião com a comunidade sobre o combate à Covid-19, onde os moradores foram informados sobre o resultado da investigação e, portanto, sobre a continuidade da barreira. No dia 2 de julho foi realizado o segundo encontro sobre o tema, no qual os participantes foram informados sobre o sistema de bandeiras estabelecido pela prefeitura municipal e foi definida a permissão para entrada de materiais de construção na comunidade. No dia 3 de julho, representantes da comunidade se reuniram com a Secretaria Municipal de Turismo para saber como seria a retomada da atividade turística no município e como o governo controlaria a entrada de turistas em Trindade. No dia 10 de julho, a prefeitura municipal anunciou a possibilidade 
de reabrir a cidade ao turismo a partir do dia 15 de agosto. Com isso, a comunidade se reúne pela terceira vez, no dia 13 de julho, e tendo em vista a previsão de reabertura ao turismo feita pela cidade, é definido um procedimento para permitir a entrada de empregados não residentes 2 dias por semana. Preocupada em preparar a comunidade para o acolhimento seguro dos turistas, a AMOT lançou no dia 22 de julho o Plano de Reabertura Segura, que prevê cursos preparatórios sobre os protocolos de reabertura de empresas. O primeiro curso, realizado no dia 29 de julho, abordou os protocolos de reabertura do setor de alimentação e o segundo, realizado no dia 5 de agosto, abordou os protocolos de reabertura do setor de hospedagem. No entanto, ao contrário da previsão inicial, o poder público municipal antecipou a reabertura da cidade ao turismo (mudança para bandeira azul) para o dia $1^{\circ}$ de agosto. Assim, a comunidade mobilizou-se rapidamente, fazendo um pedido e enviando uma carta para informar a manutenção da barreira e solicitar apoio para que as atividades turísticas em Trindade só pudessem ser retomadas a partir do dia 15 de agosto.

Apesar de Trindade ser um dos locais mais visitados do concelho, a sua barreira de saúde comunitária resistiu mais 15 dias, enquanto o turismo na cidade já se tinha restabelecido. A partir de 15 de agosto, a barreira deixa de bloquear os não residentes e passa a ter a função de contar e orientar os turistas sobre os procedimentos de segurança sanitária.

Em seus quase 5 meses de resistência, a barreira comunitária de Trindade foi fundamental para a proteção de seus habitantes. Apenas 4 casos de Covid-19 foram confirmados na comunidade, enquanto nos bairros vizinhos o número foi muito maior (Figura 4). Segundo dados coletados por voluntários da barreira, só no mês de julho (que tem um alto índice de visitas), cerca de 2.000 turistas foram proibidos.

Além da proteção que a barreira proporcionava aos moradores em termos de saúde pública, também era importante reafirmar a relação da comunidade Caiçara com seu território, segundo um dos líderes caiçaras, Davi Paiva, lembrando que:

uma das coisas mais belas e positivas que aconteceram durante a barreira foi a redescoberta da comunidade de seu próprio território. [...] Muita gente que normalmente não ia às praias, que não ia à cachoeira e os idosos que não andavam muito, porque Trindade estava completamente vazia, conseguiram sair. Então começamos a encontrar pessoas que normalmente não víamos. A natureza rapidamente se tornou mais forte de uma maneira muito bonita de ver. E eu sinto que a comunidade se sentiu muito mais confortável, apesar da pandemia, porque Trindade estava fechada, sem turismo. E dentro do perímetro da Trindade caminharam e caminharam. Na medida do possível. Não é que eles tenham caminhado o tempo todo, mas senti que muitas pessoas 
aproveitaram esse momento para aproveitar mais os recursos naturais da comunidade, para curtir mais a natureza. E agora [depois de abrir a barreira], ao contrário, vejo os idosos com muito medo de sair de casa. Eu vejo muitas pessoas que estão trancadas em casa. Assim, o território voltou a ser dominado por turistas. Quem precisa trabalhar está trabalhando, por responsabilidade e por causa da situação econômica. E quem não está trabalhando, fica dentro de casa. A comunidade evita o contato com turistas em geral e se sente muito acuada pelo grande volume de turistas.

Figura No 4: Número de casos de Covid-19 em Paraty (total), comunidades de Praia do Sono e Trindade e comunidades vizinhas sem barreiras, entre 9 de abril e 27 de agosto de 2020

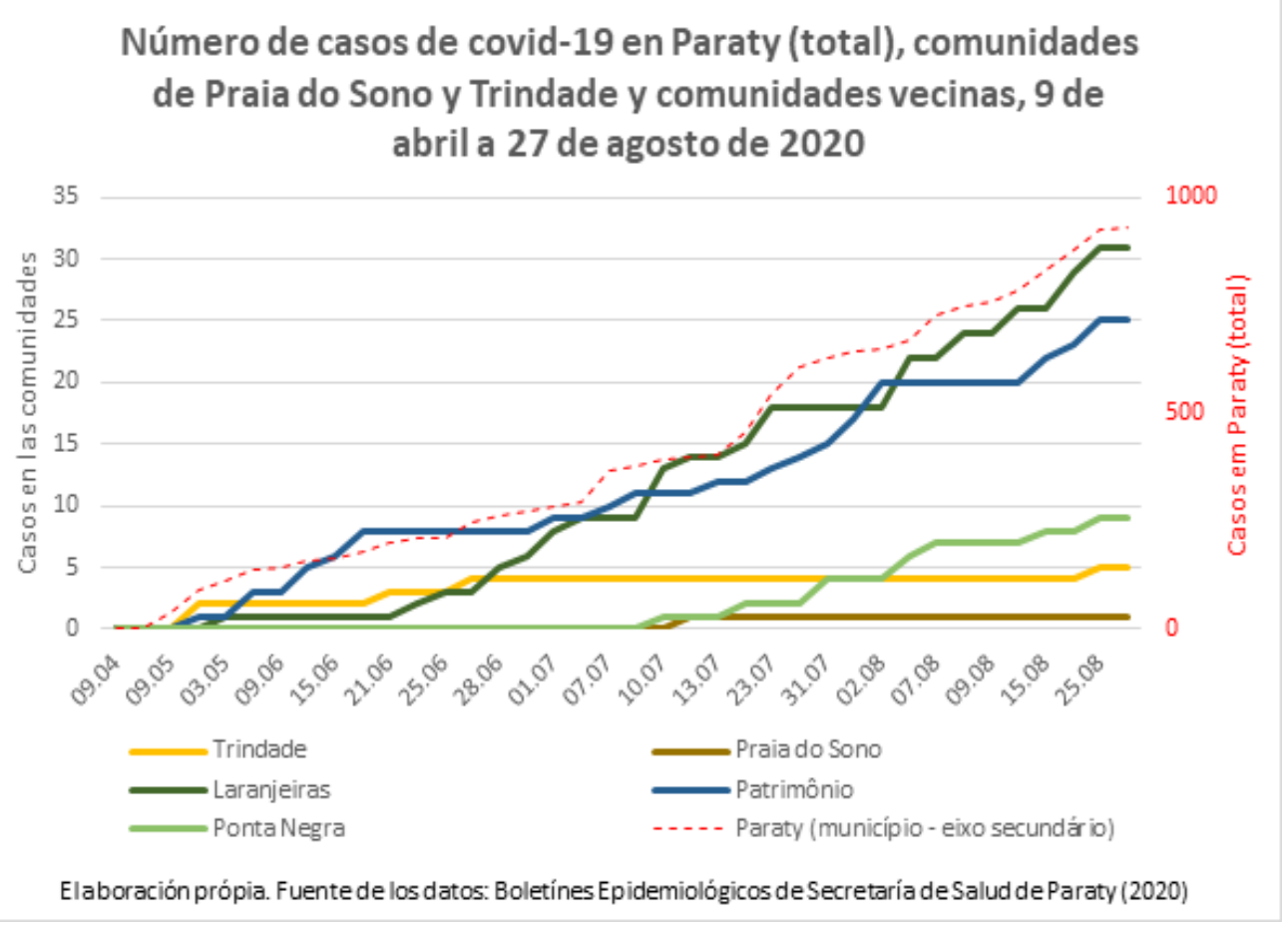

\section{PRAIA DO SONO}

A comunidade da Praia do Sono foi a primeira a interromper os serviços turísticos, promovendo inicialmente esse fechamento apenas por meio de declarações públicas e não por meio de bloqueio físico de acesso. Porém, com o aumento de casos no município e o agravamento da situação pandêmica, no mês de junho a comunidade realizou uma reunião interna, com a participação de 50 pessoas, na qual foram apresentados os boletins epidemiológicos municipais e as orientações das autoridades municipais e foram discutidos os órgãos oficiais de saúde (OMS, Secretaria Municipal de Saúde, Fiocruz etc.) e chegou-se a um consenso sobre a necessidade de garantir a segurança dos moradores por meio de uma barreira de saúde comunitária. A partir do dia seguinte, 24 de junho, os comunitários se revezaram em duas paradas diárias de 3 pessoas em uma barreira estruturada com mesa, cadeiras e faixas informativas - localizada na trilha, único acesso 
ao terreno, próximo à entrada da comunidade. A Praia do Sono, que tem cerca de 350 habitantes, conseguiu organizar a sua comunicação e os deslocamentos da barreira por meio de um grupo de WhatsApp com 150 voluntários e, com menos frequência, por meio de encontros presenciais.

Figura $\mathbf{N}^{\circ}$ 5: Barreira da comunidade de Praia do Sono.

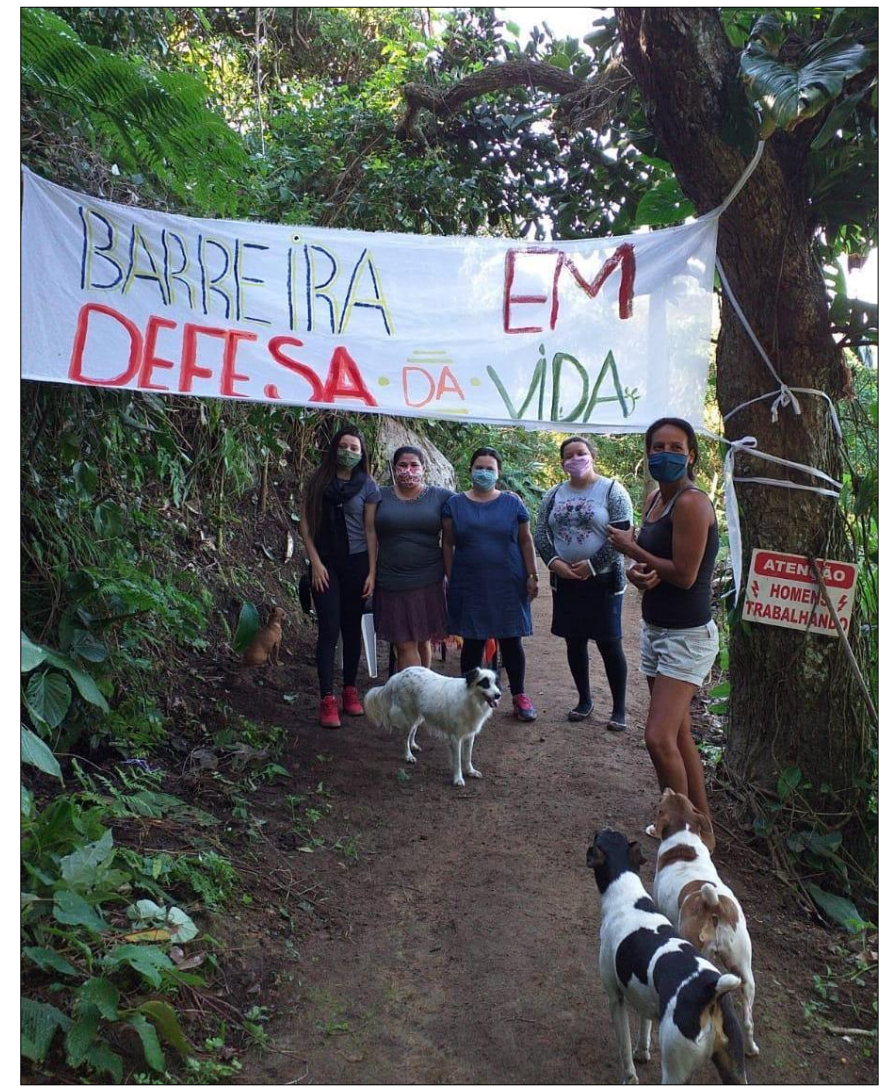

Fonte: AMOSONO

Segundo um dos líderes Jardson dos Santos, que integra a Associação de Moradores Originários da Praia do Sono, as portarias da prefeitura tiveram um importante papel inicial para frear a expansão da Covid-19, mas não demorou e o poder municipal começou a diminuir a necessidade de isolamento social para conter a doença. Uma das principais preocupações que levaram os caiçaras da Praia do Sono a impor o bloqueio foi o fato de a comunidade possuir muitos idosos, com histórico de diabetes e hipertensão, o que os faz pertencer ao grupo mais sujeito a complicações por contaminação por coronavírus. Para as comunidades caiçaras, assim como para outras culturas tradicionais, os idosos são muito respeitados e valorizados por carregarem a história da comunidade e por serem dotados de muita experiência e sabedoria. Na Praia do Sono, essa relação com os idosos é ainda mais intensa, pois eles faziam parte do processo de combate à grilagem 
e especulação imobiliária que garantia a permanência da comunidade em seu território no passado.

As restrições estabelecidas com o cenário de barreira determinavam que apenas os atuais moradores pudessem utilizar o caminho ou o barco para entrar ou sair da comunidade. Os turistas e até mesmo parentes não residentes eram impedidos de entrar, exceto nos casos de emergência. Esse controle gerou diversos conflitos, desde os causados por turistas, agências de turismo e guias do município de Paraty, que invocaram o direito público de acesso à praia, até comunidades vizinhas não favoráveis às medidas impostas, ou mesmo parentes não residentes, que insistiam em passar sua quarentena na comunidade. Serviços essenciais, como reparos urgentes, recebimento de contas e atendimento médico foram permitidos, mas também com restrições e com controle direto dos caiçaras.

Nas situações em que os não residentes tentaram entrar na comunidade por meio de intimidações ou ameaças, ou mesmo naquelas em que conseguiram, devido à falta de barreira durante o turno da noite, por exemplo, os caiçaras chamaram um maior número de moradores para conversar ou avisaram a equipe da Reserva Ecológica Estadual da Juatinga, área protegida que se sobrepõe à comunidade da Praia do Sono. Esse tipo de situação provocou um debate interno sobre como efetivar o impedimento estabelecido coletivamente, ou melhor, sobre qual é o real poder da comunidade para fazer cumprir as normas por ela estabelecidas, ou quais são os limites de sua autonomia ou do controle que ela pode exercer.

Ao mesmo tempo em que as decisões e regras são estabelecidas pela comunidade, às vezes a competência para executá-las depende de ações diretas do poder público. No entanto, a autonomia e a capacidade organizacional da comunidade não podem ser medidas com base no domínio que tem para operar todo o processo, mas também se expressa através da sua capacidade de articular redes de apoio com atores-chave em momentos de necessidade. Assim, a comunidade contou com o apoio da Reserva Ecológica Estadual da Juatinga para a confecção de algumas faixas e auxílio da equipe de fiscalização, quando solicitado. A Área de Proteção Ambiental Cairuçu, outra área protegida que se sobrepõe ao território caiçara, contribuiu com as portarias que sinalizaram o fechamento da comunidade. O Ministério Público Federal, por sua vez, recomendou oficialmente que as comunidades tradicionais fossem ouvidas em qualquer ação estadual relacionada à proteção contra a Covid-19. Outro apoio importante foi o Fórum de Comunidades Tradicionais, movimento social que luta pelos direitos dos povos 
tradicionais da região, que fez um levantamento com pessoas em situação de vulnerabilidade e doou mais de 800 cestas básicas (com elementos da agricultura orgânica e pesca artesanal) e higiene para a comunidade. Houve também um pouco de apoio da Secretaria Municipal de Assistência Social e da Secretaria Municipal de Educação, que distribuía alimentos para as crianças que pararam de comer nas escolas fechadas por conta da pandemia. E, por sua vez, o Programa de Educação Ambiental (PEA), por meio de rádios comunitárias, ajudou a levar informações sobre a Covid-19 em uma linguagem de fácil compreensão, e o projeto de extensão da Universidade Federal do Rio de Janeiro, intitulado Raízes e Frutos, doou máscaras para os moradores.

Em agosto, o poder público municipal de Paraty abriu a cidade ao turismo e também anunciou a retirada das placas de restrição à Praia do Sono. Essa situação levou a comunidade a se organizar e, por escrito, esclareceu que a praia não é só município, mas também faz parte de um território tradicional. Apesar dos diversos decretos que permitiam visitas públicas, os caiçaras da Praia do Sono decidiram manter a comunidade e a barreira sanitária fechadas, enfatizando a sua independência na tomada de decisões. Mais uma vez, foi organizada uma rede de apoio e, com a ajuda do Ministério Público Federal, dos órgãos ambientais e da recém-criada Secretaria Municipal Adjunta de Comunidades Tradicionais, os comunitários passaram a construir coletivamente um protocolo interno com o objetivo de estabelecer suas próprias regras de abertura ao turismo, de acordo com seus critérios de segurança.

A barreira sanitária criada e mantida pelos caiçaras da Praia do Sono foi reconhecida no município e sua importância e eficácia são evidentes, pois é a comunidade com menor número de casos de contaminação - apenas uma pessoa foi infectada fora da comunidade e não houve transmissão interna. No entanto, a opinião da comunidade sobre a necessidade da barreira sanitária não é uniforme. Embora a grande maioria fosse favorável ao bloqueio, algumas pessoas se posicionaram na direção oposta, principalmente pela necessidade de manter suas fontes de renda. Jardson dos Santos reconhece que o fechamento da comunidade ao turismo trouxe prejuízos econômicos, mas destaca que esses efeitos são mais brandos do que em outras localidades, pois na Praia do Sono as pessoas plantam, pescam, conhecem a natureza e seus recursos, destacando assim a importância de o território para garantir os meios de existência e a soberania alimentar para a produção da vida. 
Ainda segundo o dirigente, a situação da pandemia e a própria barreira sanitária suscitaram debates importantes no quotidiano da comunidade, não só relacionados com a questão da saúde, mas também sobre organização social, gestão do território, cultura e turismo predatório. Para Jardson,

o legado que fica é que temos que refletir muito no mundo, no Brasil, no Rio de Janeiro, em Paraty e nas comunidades. Infelizmente, dependemos do turismo predatório em Paraty, mesmo em comunidades tradicionais. [...] Que a gente possa realmente aproveitar essa pandemia para fazer novas inserções na comunidade, nos fortalecer mais, para criar uma discussão de dentro para fora, de uma perspectiva de quem realmente merece, a gente tem que olhar com mais carinho, que a gente ter mais voz levada a sério pelos governantes. Outro legado que fica é a autonomia do território, é muito importante, ainda vivemos em um sistema em que delegamos poder aos outros, através do voto, isso é muito ruim, é uma forma de despolitizar nosso povo, toda vez nós temos que fazer isso. [...] o que a gente está fazendo colocando a vida em primeiro lugar é construindo história, é um marco, construindo a defesa do território, estamos dando exemplo para essa sociedade capitalista.

\section{CONCLUSÃO}

Na América Latina / Abya Yala, frente à pandemia de Covid-19, assistimos ao surgimento e / ou consolidação de processos territoriais autônomos liderados por diversos grupos historicamente subordinados, que passaram a defender seus territórios de forma mais contundente, impondo suas próprias regras de acesso e circulação para além ou mesmo contra as diretrizes estabelecidas pelo Estado. Foi nesse contexto de tensão provocada pela pandemia que as comunidades caiçaras de Trindade e Praia do Sono levantaram barreiras sanitárias, estabelecidas por meio de arranjos comunitários, dada a impossibilidade do poder público de garantir o isolamento e a segurança física dessas populações tradicionais, constantemente pressionadas pelo turismo. O sentido não era só de encerramento de territórios, mas também de autonomia na gestão da vida, retomando os termos do léxico de luta pela vida, dignidade e território, que vem se instaurando no continente há duas décadas (PORTO -GONÇALVES, 2015).

Alguns aspectos devem ser destacados da experiência em análise. A situação de pandemia fez com que os olhares se voltassem mais uma vez para duas comunidades, que no passado viveram conflitos territoriais importantes e que têm uma história de luta e resistência resgatada na memória coletiva e reconhecida no âmbito do município e da região. As experiências de mais de quatro décadas de conflito, com pressões de projetos de desapropriação, fazem com que a própria história seja o exemplo para o enfrentamento de situações críticas. Atualmente, foram as duas comunidades que se destacaram no cenário municipal por demonstrarem forte capacidade organizacional e rápida resposta 
para a proteção de suas populações, para as quais alcançaram níveis de contaminação muito baixos em relação às comunidades próximas.

A dimensão econômica dos efeitos da pandemia e das barreiras levantadas nas duas comunidades deve ser levada em consideração. Quase todos os habitantes das comunidades vivem dos seus próprios meios, seja do transporte marítimo, do aluguel de camping e de casas para turistas, seja da pesca. As práticas agrícolas também estão presentes, como suporte à alimentação. $O$ fato é que a grande maioria não tem empregador, e se por um lado isso facilita a decisão de interromper o trabalho, visto que têm independência para o fazer, por outro lado, existem pressões económicas para se abrirem a barreira de manifestações de dentro da própria comunidade, reforçando as relações internas. É importante destacar que a emergência levantou a questão da soberania alimentar e fez com que muitas famílias que haviam abandonado suas lavouras voltassem à produção. Mesmo assim, muitos deles tiveram que se sustentar por meio de doações de alimentos que foram organizadas por associações de moradores em conjunto com o Fórum de Comunidades Tradicionais.

O controle da entrada e saída da comunidade também destaca a dimensão da própria vida da comunidade e levanta questões importantes para análises futuras. Quem são os que pertencem ou não à comunidade? Como se vivencia o cuidado coletivo na dimensão individual e vice-versa? Em que medida as pessoas confiam a sua defesa às iniciativas decididas nas assembleias e postas em prática pelas próprias pessoas?

Como Gutiérrez (2018), entendemos que, mesmo em comunidades tradicionais, as relações comunitárias cooperativas não têm uma existência prévia ou uma existência em si mesmas, mas precisam ser produzidas ativamente, em um fazer e refazer constante e dedicado. Nesse sentido, assim como a autora, acreditamos que enfrentando problemas e necessidades comuns e exercendo o cuidado cotidiano, como fazem as comunidades de Trindade e Praia do Sono, é possível gerar um entendimento da transformação social, como uma subversão sistemática da ordem de dominação existente, capaz de gerar vínculos coletivos capazes de sustentar a reprodução da vida.

O mundo pós-Covid-19 deve colocar em perspectiva uma combinação variável entre o retorno aos padrões anteriores e a sedimentação de novas formas de controle populacional em diferentes níveis, vivenciadas na emergência. No caso das experiências comunitárias, não são apenas os controles externos que traçam o horizonte futuro, mas também como eles respondem aos desafios. Para as comunidades que passaram pela experiência do autoisolamento e da defesa da vida em seus territórios, é também um 
marco na história dos conflitos e afetos, matéria-prima das formas de conhecer e estar no território.

\section{NOTAS}

* A comissão editorial da Revista Tamoios agradece ao corpo de avaliadores da Revista Cardinalis

1 - Publicado originalmente em castelhano na Revista Cardinalis Vol. 8 Núm. 15 (2020): “Dossier: Pandemia y espacio geográfico: problemáticas, desafíos y perspectivas".

\section{REFERÊNCIAS BIBLIOGRÁFICAS}

AGNEW, John; OSLENDER, Ulrich. Territorialidades superpuestas, soberanía en disputa: lecciones empíricas desde América Latina. Tabula Rasa, n. 13, p. 191-213, 2010.

BEGOSSI, Bruna Oliveira; CAVICHIOLO, Mariana Passos; GURGEL, Cristina Brandt Friedrich Martin. Pressão sanguínea e hipertensão entre pescadores costeiros do sudeste do Brasil. In: Alpina Begossi; Priscila F. M. Lopes (orgs) Comunidades pesqueiras de Paraty: sugestões para manejo. São Carlos: RiMa Editora, 2014.

BONILLA, Victor D.; CALSTILLO, Gonzalo; FALS BORDA, Orlando; LIBREROS, Augusto. Causa popular, ciência popular: una metodología del conocimiento científico a través de la accíon. Serie: Es ahi es la cosa. N.2. Rosca: Bogotá, 1972.

CIPOG-EZ; FNLP; OCSS. Comunicado conjunto del Concejo Indígena y Popular de Guerrero - Emiliano Zapata, Frente Nacional de Liberación de los Pueblos - FNLP y Organización Campesina de la Sierra Sur - OCSS ante el contexto actual, 30 de marzo de 2020. Disponible en https://www.congresonacionalindigena.org/2020/04/21/comunicado-conjunto-del-concejo-indigena-ypopular-de-guerrero-emiliano-zapata-cipog-ez-frente-nacional-de-liberacion-del-pueblos-fnlp-yorganizacion-campesina-de-la-sierra-del-sur-ocss-ante-el-cont-2/. Acceso en 21 septiembre de 2020.

COMISSÃO NACIONAL DA VERDADE (CNV). Violações de Direitos Humanos dos Povos Indígenas. In: CNV. Relatório Final da Comissão Nacional da Verdade, dezembro 2014. Disponible en http://cnv.memoriasreveladas.gov.br/images/pdf/relatorio/Volume\%202\%20-\%20Texto\%205.pdf, Acceso en 21 septiembre de 2020.

COMISSÃO PASTORAL DA TERRA (CPT). Relatório Conflitos no Campo 2020. Disponible en https://www.cptnacional.org.br/component/jdownloads/send/41-conflitos-no-campo-brasilpublicacao/14195-conflitos-no-campo-brasil-2019-web?Itemid=0. Acceso realizado en: 21 septiembre de 2020 .

CONFEDERACIÓN DE NACIONALIDADES INDÍGENAS DE ECUADOR (CONAIE). Conaie dispone mantener la cuarentena en comunas, comunidades, pueblos y nacionalidades indígenas. 27 abril 2020. Disponible en https://conaie.org/2020/04/27/conaie-dispone-mantener-la-cuarentena-en-comunascomunidades-pueblos-y-nacionalidades-indigenas/. Acceso en 21 septiembre de 2020.

CONSELHO INDÍGENA MISSIONÁRIO (CIMI). Relatório Violência contra os Povos Indígenas no Brasil: Dados de 2018. CIMI, 2019. Disponible en https://cimi.org.br/wpcontent/uploads/2019/09/relatorio-violencia-contra-os-povos-indigenas-brasil-2018.pdf. Acceso en 21 septiembre de 2020 .

CRUZ, Valter do Carmo. Geografia e pensamento descolonial: notas sobre um diálogo necessário para a renovação do pensamento crítico. In: Valter do Carmo Cruz; Denilson Araújo de Oliveira (org) Geografia e giro descolonial: experiências, ideias e horizontes de renovação do pensamento crítico. Rio de Janeiro: Letra Capital, p. 15-36, 2017.

DIEGUES, Antonio Carlos. Povos e Águas: inventário de áreas úmidas brasileiras. 2 ed. São Paulo: NUPAUB-USP, 2002. 597 p.

EJÉRCITO ZAPATISTA DE LIBERACIÓN NACIONAL (EZLN). Comunicado del Comité Clandestino Revolucionário Indígena, Comandancia General del Ejército Zapatista de Liberación Nacional. México, 
16 de marzo de 2020. Disponible en http://enlacezapatista.ezln.org.mx/2020/03/16/por-coronavirus-elezln-cierra-caracoles-y-llama-a-no-abandonar-las-luchas-actuales/. Acceso realizado en: 21 septiembre de 2020 .

FARO, Amanda Regis. Sobreposições e tensões territoriais no ordenamento da comunidade caiçara da praia do sono, Paraty-RJ. In: IX Simpósio Internacional de Geografia Agrária e X Simpósio Nacional de Geografia Agrária, 9, 2019, Recife. Anais. No publicado.

FEITOSA, Annagesse; SILVA, Iby Montenegro de. Conflitos por terra e repressão no campo na região da Costa Verde, Litoral Sul Fluminense. In: Conflitos Por Terra e Repressão no Campo no Estado do Rio de Janeiro. (1946-1988). (Coordenadora: Leonilde Servolo de Medeiros). CPDA-UFRRJ. 2015.

GUTIÉRREZ Aguilar, Raquel. Horizonte comunitario-popular: antagonismos y producción de lo común en América Latina. Chuimeq'ena': Sociedad Comunitaria de Estudios Estratégicos, 2016.

GUTIÉRREZ Aguilar Raquel; LINSALATA, Lucia; NAVARRO, Mina Lorena. Repensar lo político, pensar lo común: claves para la discusión. INCLÁN, Daniel; LINSALATA, Lucia; MILLÁN, Márgara. Modernidades alternativas. Cidade do México: Facultad de Ciencias Políticas y Sociales UNAM, Ediciones del Lirio, p. 377-417, 2017.

GUTIÉRREZ Aguilar, Raquel. Comunalidad, tramas comunitarias y producción de lo común: debates contemporáneos desde América Latina. Oaxaca, México: Colectivo Editorial Pez en el Árbol, Editorial Casa de las Preguntas, 2018.

HAESBAERT, Rogério. Da desterritorialização à multiterritorialidade. Anais: Encontros Nacionais da ANPUR, 9, 2013.

HAESBAERT, Rogério. Viver no limite: território e multi/transterritorialidade em tempos de insegurança e contenção. Rio de Janeiro: Bertrand Brasil, 2014.

HAESBAERT, Rogério. Do muro ao drone: novos-velhos dispositivos geográficos de segurança. In: J. N. Rodrigues e L. C. Rego Monteiro (org). Crise e reinvenção dos espaços da política. Rio de Janeiro: Consequência, 2020.

IBGE - INSTITUTO BRASILEIRO DE GEOGRAFIA E ESTATÍSTICA. Estimativas da população residente para os municípios e para as unidades da federação brasileiros com data de referência em $1^{\circ}$ de julho de 2020. Rio de Janeiro, 13p. 2020. Disponible en https://biblioteca.ibge.gov.br/index.php/bibliotecacatalogo?view=detalhes\&id=2101747. Acceso realizado en noviembre de 2020.

KAÊ GUAJAJARA. Rap indígena trilíngue sobre a pandemia do coronavírus. Disponible en https://www.youtube.com/watch?v=3NmY2F61GY8. Acceso en: 21 septiembre de 2020.

LEPERCQ, Claire/Rio On Watch. Policiais militares são acusados pela morte de jovem em Trindade, Paraty. Rio On Watch, 12 octubre 2016. Disponible en https://rioonwatch.org.br/?p=22856

LOPES, Luís Carlos de Oliveira. A abertura da Rio-Santos e os conflitos pela terra. In: Iaci. S. Mattos; L. C. Rego Monteiro; D. Nobre; I. A. França (org). Uma outra história de Paraty: caderno pedagógico para projetos de educação escolar diferenciada e intercultural das escolas caiçaras de Paraty/RJ. Coletivo de Apoio à Educação Diferenciada-FCT / SME-Paraty / IEAR-UFF, 2020.

MEMÓRIAS DA DITADURA. CNV e os Indígenas. Acervo Vladimir Herzog. Disponible en http://memoriasdaditadura.org.br/cnv-e-

indigenas/\#: :text=A\%20inclus\%C3\%A3o\%20dos\%20povos\%20ind\%C3\%ADgenas,desenvolvimento\% 20adotado\%20pelo\%20Estado\%20e, Acceso en 21 septiembre de 2020.

MONGE, Ricardo Papu Martins. A disputa de Territorialidades na Península da Juatinga - Município de Paraty/RJ. 2019. 230f. Tese (doutorado em Geografia) - Universidade Federal Fluminense (UFF), Niterói, 2019.

MOREIRA, Ruy et al. O espaço e o contra-espaço: as dimensões territoriais da sociedade civil e do Estado, do privado e do público na ordem espacial burguesa. En: SANTOS, Milton et al. Território, territórios: ensaios sobre o ordenamento territorial. 2a ed. Rio de Janeiro, dP\&A, 2006.

OCMAL. 19 indígenas chilenos contagiados y en peligro por el turismo clandestino. 16 abril 2020. Disponible en https://www.ocmal.org/covid-19-indigenas-chilenos-contagiados-y-en-peligro-por-elturismo-clandestino/ Accedido en 21 septiembre de 2020.

PORTO-GONÇALVES, Carlos Walter. De saberes e de territórios: diversidade e emancipação a partir da experiência latino-americana. GEOgraphia 8(16), p. 41-55. 2006. 
PORTO-GONÇALVES, Carlos Walter. Entre América e Abya Yala - territorialidades em tensão. Desenvolvimento e Meio Ambiente, n. 20, jul/dez 2009

PORTO-GONÇALVES, Carlos Walter. Pela vida, pela dignidade e pelo território: um novo léxico teórico político desde as lutas sociais na América Latina/Abya Yala/Quilombola, Polis [En línea], 41, 2015. Disponível em http://journals.openedition.org/polis/11027. Acceso en 21 septiembre de 2020.

REGO MONTEIRO, L. C.; SILVA; L. P. B.; STEIMAN, R.; RIBEIRO, L. P. Holding the line in pandemic times: the case of Brazilian border regions (no publicado)

REGO MONTEIRO, Licio Caetano. De los controles fronterizos a la gestión de poblaciones y territorios en el espacio nacional. Presentación en ABS Summer Virtual Seminars 2000.

SIQUEIRA, Priscila. Genocídio dos caiçaras. 3 ed. São Paulo: Scortecci, 2019 [1984].

VENANCIO, Renato. Guia antropologicamente incorreto: a falácia de Narloch sobre os índios. Voyager, 19 mayo 2018. Disponible em https://avoyager.net/historia/guia-antropologicamente-incorreto/ Acesso em 21 septiembre de 2020 . 